\title{
Effect of tetracycline on the colonization and growth of microbes on Scirpus lacustris litter in oligotrophic and eutrophic waters
}

\author{
Brij Verma $^{1, *}$, Richard D. Robarts ${ }^{2}$, J. V. Headley ${ }^{3}$ \\ ${ }^{1}$ University of Saskatchewan Department of Plant Sciences, 51 Campus Drive, Saskatoon, Saskatchewan S7N 5A8, Canada \\ ${ }^{2}$ UNEP GEMS/Water Programme Office, and ${ }^{3}$ National Water Research Institute, Environment Canada, \\ 11 Innovation Boulevard, Saskatoon, Saskatchewan S7N 3H5, Canada
}

\begin{abstract}
Studies of microbes on Scirpus lacustris submerged in river (oligotrophic) and wetland (eutrophic) waters were conducted to determine how nutrient status affected colonization and growth on the same substrate. The antibiotic tetracycline was used to repress bacteria to determine if they inhibited fungal growth. The use of tetracycline was also relevant in a broader context as antibiotics are now being detected in aquatic systems. Dead $S$. lacustris stems were submerged for $33 \mathrm{~d}$ in natural and tetracycline amended (500 and $4000 \mu \mathrm{g} \mathrm{l}^{-1}$ ) river and wetland waters. Confocal laser scanning microscopy was used to scan the biofilm while image analysis was used to determine microbial (algal, bacterial, fungal) cell volume and fungal biomass by measuring the length of fungal hyphae. In all treatments, microbial cell volume peaked on Day 10 and was greater (ANOVA, all p < $0.05)$ than on all other sampling days. Microbial biovolume was higher $(p=0.04)$ in the wetland vs. river water, possibly because nutrients were not limiting in the wetland. Biofilm thickness was not different between the 2 waters, between treatments or over time ( $p=0.7,0.8$ and 0.07 , respectively). Fungal biomass was greater $(p=0.01)$ in the river water compared to the wetland, indicating that the same plant in different aquatic systems will vary in the ratio of bacterial/fungal constituents that colonize it after death. Though there seemed to be a trend of increased fungal biomass in the tetracycline treatments, suggesting bacterial inhibition of fungi, the differences were not statistically significant $(p>0.05)$. On Day 10, the controls of both water treatments had significantly greater microbial biovolume than both the 500 and $4000 \mu \mathrm{g} \mathrm{l}^{-1}$ antibiotic treatments (both $\mathrm{p}=0.02$ ), indicating that tetracycline had a negative effect on microbes colonizing Scirpus.
\end{abstract}

KEY WORDS: Macrophyte - Biofilm • Litter decomposition · Confocal scanning laser microscopy • Fungal biomass $\cdot$ Aquatic plant decay $\cdot$ Tetracycline $\cdot$ Carbon sequestration

Resale or republication not permitted without written consent of the publisher

\section{INTRODUCTION}

Plant litter decomposition in aquatic environments is a process mediated predominantly by fungi and bacteria. A variety of methods have been used to estimate the biomass and productivities of these assemblages in litter decaying systems. The methods include measuring litter mass loss (Wrubleski et al. 1997, Thormann et al. 2001) and estimating bacterial biomass by staining with DAPI (Baldy et al. 2002, Hieber \& Gessner 2002) and production by leucine incorporation (Suberkropp \& Weyers 1996). Fungal biomass and production have been estimated by counting conidia, measuring fungal hyphae, plating on nutrient media and by using ergosterol to estimate eumycotic biomass. Instantaneous rates of fungal production have been measured by using the $\left[1-{ }^{14} \mathrm{C}\right]$ acetate incorporation into ergosterol method (Newell 1996, Gessner \& Newell 2002, Verma et al. 2003). Each of these methods has its limitations. For example, ergosterol does not represent a true estimate of living fungi because it has been shown to persist in dead hyphae (Mille-Lindblom et al. 2004). The acetate to ergosterol fungal production method involves immersing decaying litter in water, even 
though the litter may be decaying above ground. Confocal laser scanning microscopy (CLSM), in conjunction with fluorescent dyes, has been utilized to study colonization by microbes on surfaces such as plastics and metals (Caldwell et al. 1992, Lawrence et al. 1998), but not to study microbes within or on the surface of decomposing litter. In the present study, we measured for the first time colonization and growth of microbes, including fungi, on decomposing litter by CLSM, fluorescent probes and image analysis.

Aquatic litter decomposition is dominated by fungi, accounting for 63 to $99 \%$ of the total microbial biomass and production (Gessner \& Newell 2002, Hieber \& Gessner 2002, Verma et al. 2003). The variability in fungal dominance may be due to the nature and carbon content of the plant substrate (Gessner et al. 1993, Baldy et al. 1995, Gulis 2001, Mille-Lindblom et al. $2006 b)$, the nature of the aquatic system or because of bacterial competition and inhibition (Moller et al. 1999, Gulis \& Suberkropp 2003). We used the emergent macrophyte Scirpus lacustris and measured the resulting microbial colonization in river (oligotrophic) and freshwater wetland (eutrophic) waters. A few studies (Flegler et al. 1974, Padgett 1993, Moller et al. 1999, Mille-Lindblom \& Tranvik 2003, Mille-Lindblom et al. 2006a) have attempted to investigate the relationships between bacteria and fungi in decomposing systems and have generally found the association to be antagonistic. However, in the majority of these studies the relationships between fungi and bacteria were assessed using culturable micro-organisms isolated from decaying litter, while only several have attempted to measure the relationships in situ (Flegler et al. 1974, Padgett 1993). Therefore, in order to define some of the ecological relationships between bacteria and fungi, we used the antibiotic tetracycline to repress bacteria so that their influence on fungal growth could be gauged. Tetracycline was used because it can be produced naturally in the environment by Streptomyces, but can also be introduced into aquatic bodies anthropogenically. It has been detected in the environment at trace levels of $<10 \mu \mathrm{g} \mathrm{l}^{-1}$ to as high as $20 \mathrm{mg} \mathrm{l}^{-1}$ in liquid manure spread on an agricultural field (Hamscher et al. 2002). There is the possibility that wetlands and waters near intensive agriculture facilities may receive high loads of this antibiotic. Therefore, this study assessed whether tetracycline disrupted microbial colonization and biomass development during plant litter decomposition.

\section{MATERIALS AND METHODS}

Water and Scirpus lacustris collection. River water was obtained from the South Saskatche- wan River (SSK) at Saskatoon, Saskatchewan, Canada $\left(106^{\circ} 38^{\prime} \mathrm{W}, 52^{\circ} 07^{\prime} \mathrm{N}\right)$ and wetland water from Pond 1 $\left(106^{\circ} 06^{\prime} \mathrm{W}, 52^{\circ} 02^{\prime} \mathrm{N}\right)$ situated at the St. Denis National Wildlife Area (NWA), Canada. Water from these sites was collected in 201 plastic containers, stored at room temperature and allowed to acclimate for $48 \mathrm{~h}$ in the laboratory before being used in experiments. Standing, dead $S$. lacustris from the previous year's stand was collected from the periphery of Pond 50, also located at the St. Denis NWA, and kept at room temperature in the laboratory prior to use in the experiments.

Experimental apparatus. The experimental apparatus consisted of sterilized $2 \mathrm{l}$ glass flasks, silicon tubing (2 mm inner diameter; Fischer Scientific) and glass tubes (10 $\mathrm{mm}$ diameter; $20 \mathrm{~cm}$ length). A Watson Marlow peristaltic 16 channel pump delivered unfiltered river and wetland water from the stock reservoir to the glass tubes that held the Scirpus lacustris stems.

Twelve Scirpus lacustris stems ( 6 $\mathrm{mm}$ in diameter) were selected and cut to a length of $14 \mathrm{~cm}$. Expt 1, with river water, consisted of 3 duplicate treatments: the control treatment comprised river water without amendments while the second and third treatments were river water spiked with tetracycline at 500 and $4000 \mathrm{Mg} \mathrm{l}^{-1}$, respectively. These concentrations were used because studies have shown that attached bacteria are more resistant to antibiotics than planktonic bacteria by a factor of 100 to 1000 (Wolfaardt et al. 1999). We previously found that planktonic bacteria were affected by tetracycline concentrations as low as $10 \mu \mathrm{g} \mathrm{l}^{-1}$ in the river and $2 \mathrm{mg} \mathrm{l}^{-1}$ in the wetland water used in the present study (Verma 2007). In addition, the amended concentrations fell well within the $\mu \mathrm{g} \mathrm{l}^{-1}$ to $\mathrm{mg} \mathrm{l}^{-1}$ range reported in the aquatic and soil environment, respectively.

Expt 2 was the same as Expt 1 except that Pond 1 water was used. In both experiments, water was run through the experimental apparatus for $3 \mathrm{~d}$ prior to the introduction of stems to acclimate the tubing and glassware to the water as well as to allow tetracycline (in the tetracycline treatments) to bind to any active binding sites in the experimental apparatus. The flow rate of the water was $6 \mathrm{ml} \mathrm{h}^{-1}$ and the stems in the glass tubes were continuously exposed to the natural and tetracycline amended waters for the $33 \mathrm{~d}$ experimental duration. The water reservoirs were replenished daily and spiked with tetracycline dissolved in water that had passed through a $0.2 \mu \mathrm{m}$ pore-size membrane filter.

Confocal laser scanning microscopy. CLSM was used to measure (Day 0 prior to submersion, and Days $7,10,15,24$ and 33) changes in the colonization of microbes and formation of a biofilm on the surface of Scirpus lacustris stems in river and wetland water, in 
the presence or absence of tetracycline. Before scanning with the CLSM, decaying $S$. lacustris stems were removed from the glass tubes and placed in an 'observation apparatus'. The apparatus was constructed of polyvinyl chloride and held water, thus allowing submersion of the stem and easy scanning by CLSM. The biofilm on the stem was stained with the nucleic acid binding stain SYTO-9 (Excitation $488 \mathrm{~nm}$, emission $500 \mathrm{~nm}$; Molecular Probes). A working solution of SYTO-9 was prepared by pipetting $2 \mu \mathrm{l}$ of the stain into $1 \mathrm{ml}$ of sterile distilled water and this working solution was pipetted directly onto a randomly selected portion of the stem. Because SYTO-9 slowly degrades in light, it was applied under subdued light, but as a further precaution the observation apparatus was covered with aluminum foil until being scanned. Fifteen minutes were allowed for SYTO-9 to penetrate the biofilm and stain the cells. To keep the stem and biofilm hydrated and active, the observation apparatus was filled with water from the same treatment as the stem under observation to completely immerse the stem. Laser scans of the biofilms were carried out using an MRC 1024 CLSM (Biorad) attached to a Microphot SA Microscope (Nikon). For observation, a $40 \times 0.55$ Numerical Aperture (Nikon) water immersion lens was used.

The SYTO-9 stained part of the biofilm was scanned from the top, the point at which a microbe was observed at the center of the field of view, to the surface of the Scirpus lacustris stem at $5 \mu \mathrm{m}$ intervals. This single scan represented one z-series, which consisted of a stack of 21 images if the biofilm was $100 \mu \mathrm{m}$ thick. Ten z-series of the biofilm per stem ( 2 stems per treatment) were collected on each sampling day. Image analysis was performed in Scion Image Beta 4.02. Microbial (algal, bacterial, fungal) cell volume was determined by measuring the cell area in every image of the z-series and summing the cell area of the total number of slices or images within the z-series (Lawrence et al. 1997, 1998). NIH Image 1.61 (http:// rsb.info.nih.gov/nih-image/) was used to perform image analysis. It is important to note that the biovolume measured by CLSM and determined by image analysis is treated as an indicator of microbial biomass, a commonly utilized practice in biofilm research despite many inherent limitations (but see Caldwell et al. 1992 and Lawrence et al. 1997, 1998). Biofilm thickness was calculated by multiplying the $5 \mu \mathrm{m}$ intervals by the number of images, less one, in a z-series, while fungal biomass was determined by measuring the length of hyphae in each image and summing the lengths in all images within the z-series.

Water chemistry. Water chemistry was analyzed by suppressed conductivity ion-exchange chromatography on a Dionex 400 Ion Exchange chromatograph.
Statistical analysis. Statistical analysis was performed with SAS Release 9.1 for Windows. Data were analyzed using an unequally spaced repeated measures design with water (river, wetland), treatment (Control, $500 \mu \mathrm{g} \mathrm{l}^{-1}, 4000 \mu \mathrm{g} \mathrm{l}^{-1}$ ), time $(0,7,10,15,24$, and $33 \mathrm{~d}$ ) and all 2-way interactions as fixed effects. Satterthwaite's approximation to degrees of freedom was used. If the model revealed statistical significance ( $\mathrm{p} \leq$ 0.05), Tukey-Kramer adjusted comparisons were used to determine if pairwise differences existed. The microbial cell volume and fungal hyphae lengths as well as biofilm depth were normalized using a logtransformation. Parameter means \pm SE are given in 'Results'.

\section{RESULTS}

\section{Effects of tetracycline on microbial colonization of Scirpus lacustris}

Few bacterial cells and no fungal hyphae were observed on the Scirpus lacustris stems prior to wetting. Microbial (algal, bacterial, fungal) cell volume increased rapidly after submersion of the stems, peaked on Day 10, and rapidly declined thereafter (Figs. $1 \& 2$ ) in all treatments. In the river water treatments the peak levels of microbial cell volume on Day 10 were significantly higher in the control compared to the 500 and $4000 \mathrm{\mu g}^{-1}$ treatments (ANOVA, all $\mathrm{p}<0.05)$. Total cell volume produced over the $33 \mathrm{~d}$ was $1308000 \mu^{3} \mu^{-2}$ for the control treatment, and 263000 and $245000 \mu^{3} \mu^{-2}$ for the 500 and $4000 \mathrm{~g} \mathrm{l}^{-1}$ treatments, respectively. In contrast, fungal biomass, as measured by hyphae lengths, peaked on Day 7 in all 3 treatments. Total fungal hyphae generated during the $33 \mathrm{~d}$ of the experiment in the control, 500 and $4000 \mu \mathrm{g} \mathrm{l}^{-1}$ treatments was 24812 , 22312 and $66531 \mu \mathrm{m}$, respectively, but was not statistically different for river water experiments. The differences in biofilm thickness were also not significant between any of the treatments (ANOVA, p > 0.05).

In the wetland water experiments a similar trend of decreasing microbial cell volume with increasing tetracycline concentration was apparent (Fig. 2b). Total microbial cell volume measured over the course of the experiment was 2231500, 1239360 and $1003340{\mu \mathrm{m}^{3}} \mathrm{~mm}^{-2}$ for the control, 500 and $4000 \mu \mathrm{g} \mathrm{l^{-1 }}$ treatments, respectively. The increase in cell volume following wetting of the stems in the control treatment was rapid and peaked on Day 10, quickly declining thereafter. Microbial biovolume on Day 10 was significantly greater in the control compared to both the 500 and $4000 \mu \mathrm{g}^{-1}$ treatments (ANOVA, $\mathrm{p}<0.05$ ). The differences in biofilm thickness were not significant 


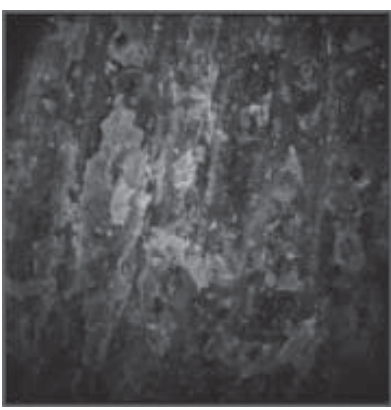

Day 0 (prior to immersion)
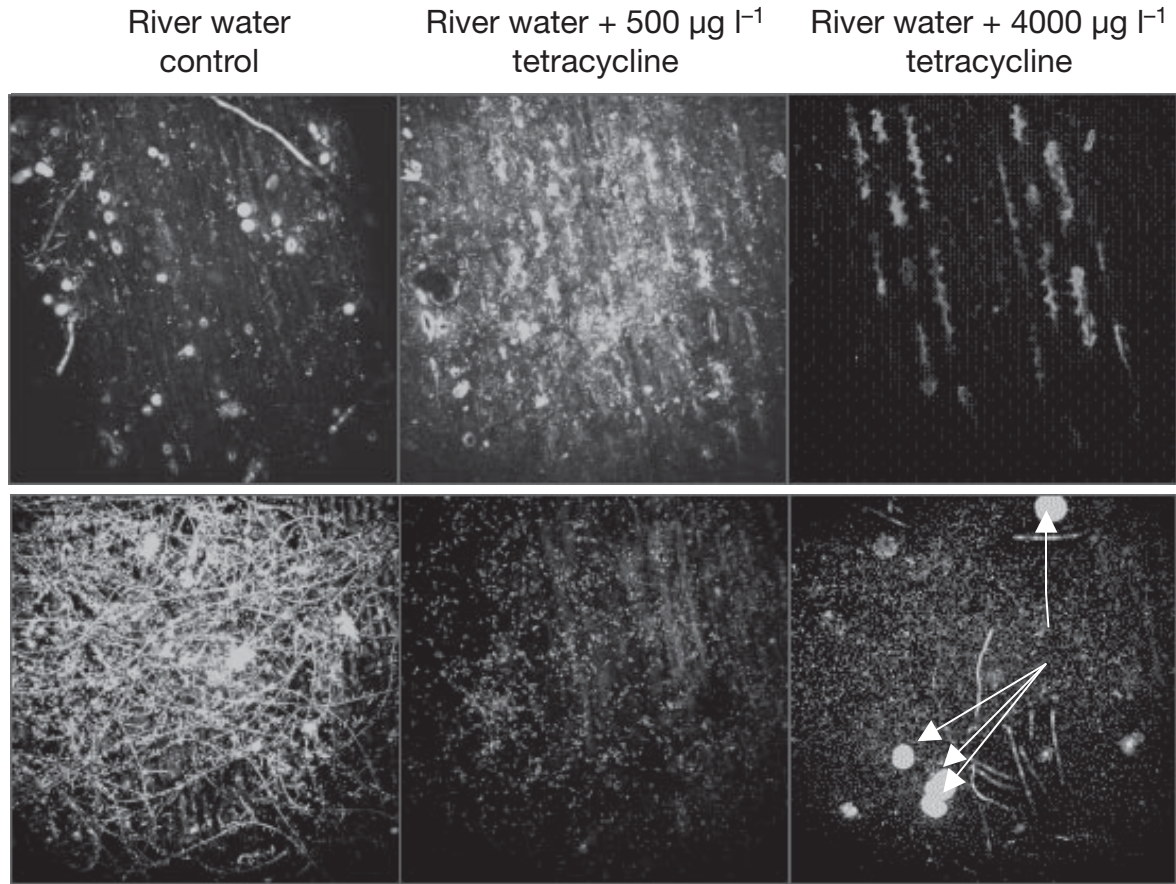

Day 10

Fig. 1. Confocal laser scanning microscopy (CLSM) scans of biofilms on Scirpus lacustris stems decaying in South Saskatchewan River water without (control) or with 500 and $4000 \mathrm{\mu g} \mathrm{l}^{-1}$ tetracycline at Days 0, 7, 10 and 15 of the $33 \mathrm{~d}$ immersion experiment. Arrows indicate algal cells. Scale bar (for all panels) $=50 \mu \mathrm{m}$

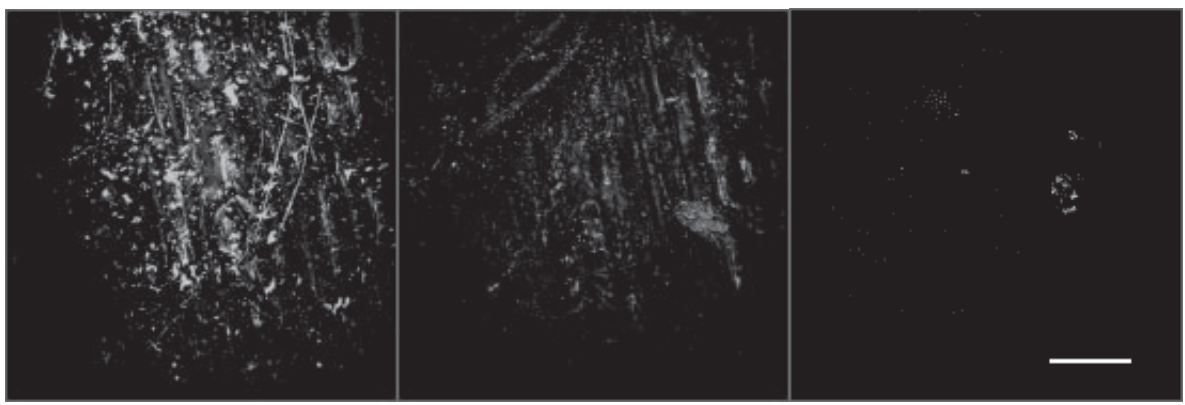

Day 15
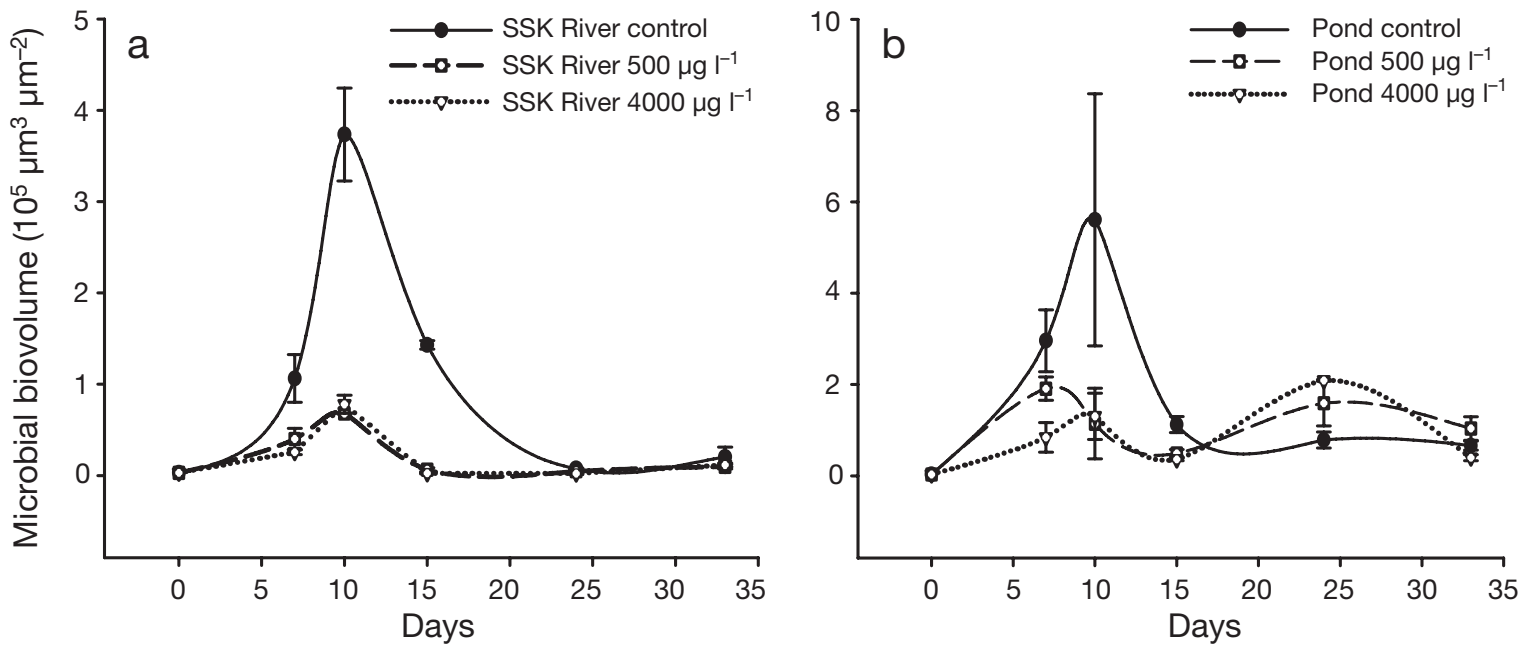

Fig. 2. Changes in microbial (algal, bacterial, fungal) biovolume, as measured by CLSM and image analysis over $33 \mathrm{~d}$ on the surface of Scirpus lacustris stems decaying in (a) South Saskatchewan River (SSK) water (control) and (b) Pond 1 water (control) and in water of the respective systems amended with 500 and $4000 \mu \mathrm{g} \mathrm{l}^{-1}$ tetracycline. Data points are treatment means $\pm \mathrm{SE}(\mathrm{N}=2)$ 
Table 1. Water chemistry of the South Saskatchewan River (SSK) and Pond 1

\begin{tabular}{|lcccccc|}
\hline $\begin{array}{l}\text { Water } \\
\text { system }\end{array}$ & $\begin{array}{c}\mathrm{Cl} \\
\left(\mathrm{mg} \mathrm{l}^{-1}\right)\end{array}$ & $\begin{array}{c}\mathrm{NO}_{3} \\
\left(\mathrm{mg} \mathrm{l}^{-1}\right)\end{array}$ & $\begin{array}{c}\mathrm{SO}_{4} \\
\left(\mathrm{mg} \mathrm{l}^{-1}\right)\end{array}$ & $\mathrm{pH}$ & $\begin{array}{c}\text { Alkalinity } \\
\left(\mathrm{mg} \mathrm{l}^{-1} \mathrm{CaCO}_{3}\right)\end{array}$ & $\begin{array}{c}\mathrm{DOC} \\
\left(\mathrm{mg} \mathrm{l}^{-1}\right)\end{array}$ \\
\hline SSK & 7.50 & 0.4 & 71 & 8.3 & 96 & 3.3 \\
Pond 1 & 76.0 & 1.5 & 4065 & 7.5 & 149 & 48.8 \\
\hline
\end{tabular}

tions. These results indicated that microbial production in the river may be limited by inorganic and organic nutrients. They are not limiting to microbial planktonic production in Pond 50 (means \pm SE for 1993 to 1996: total $\mathrm{N}=2.9 \pm 1.1 \mathrm{mg} \mathrm{l}^{-1}, \mathrm{DOC}=53.2 \pm$ $16.2 \mathrm{mg} \mathrm{l}^{-1}$, total P was $0.23 \pm 0.17$ ), or Pond 1, during most of the summer between any of the treatments due to variability in the data (ANOVA, p > 0.05). Total fungal hyphae produced over the $33 \mathrm{~d}$ of the experiment in the control, 500 and $4000 \mu \mathrm{g} \mathrm{l}^{-1}$ treatments were 1680, 5658 and $10110 \mu \mathrm{m}$, respectively. There was a trend of increasing fungal hyphae with increasing tetracycline concentration, but the difference between the wetland water treatments was not statistically significant (ANOVA, p > 0.05) due to large variations.

The wetland water treatments had significantly higher microbial cell volume (ANOVA, $\mathrm{p}=0.04$ ) but not biofilm thickness (ANOVA, $p=0.7$ ) than the river water. Nutrient and dissolved organic carbon (DOC) concentrations were greater in the wetland (Table 1). However, significantly greater amounts of fungal hyphae were measured in the river water (ANOVA, $p=0.01$ ).

\section{DISCUSSION}

Submergence of Scirpus lacustris stems in both river and wetland waters, regardless of the presence or absence of tetracycline, resulted in a dramatic increase in microbial biovolume and fungal hyphae that peaked at 7 to $10 \mathrm{~d}$ before subsiding. Our data confirm the increase in microbial cell volume following submergence of dry litter in other studies (Newell 2003), which is likely due to the availability of moisture, a limiting factor for microbes in/on standing litter.

Microbial (algal, bacterial, fungal) cell volume in the eutrophic wetland was approximately twice that observed for the river system. This was to be expected because freshwater wetlands are one of the most productive systems in the Northern Prairies (Van Der Valk \& Davis 1978). The wetland water was much more enriched in nitrogen and DOC (Table 1) as well as other nutrients compared to the river system (Waiser 2001). In the river in 2005 the concentration of total nitrogen ranged between 0.19 and $0.3 \mathrm{mg} \mathrm{l}^{-1}$ and that of total phosphorus between 0.01 and $0.1 \mathrm{mg} \mathrm{l}^{-1}$ (City of Saskatoon unpubl. data). DOC varied between 3.2 and $4.1 \mathrm{mg} \mathrm{l}^{-1}$. Recently, Neu et al. (2005) found that the addition of DOC (glucose), nitrogen and phosphorus increased the thickness of biofilm grown in SSK water. Phosphorus additions also produced a small increase in biofilm thickness but not nitrogen addi- season (Waiser 2001). These differences in nutrient availability likely resulted in the lower productivities on the stems decaying in river water.

There were about 15 times more fungal hyphae measured in the river control treatment vs. the wetland control treatment. This indicates that fungal colonization of the same plant in different waters will vary, and in turn suggests that fungal dominance on the same decomposing plant can significantly differ between different water systems. The lower fungal hyphae production on Scirpus lacustris in the wetland water may have been due to a lack of representative fungal species able to utilize the stem as a carbon and nutrient source. This is unlikely, however, because the stems were harvested from around the wetland, and fungi capable of degrading $S$. lacustris should be more abundant in the wetland compared to the river. Previous studies, and a recent one by Mille-Lindblom et al. (2006b), have suggested that for a given substrate, a lower nitrogen content is more amenable to fungi and a higher phosphorus to bacteria. However, in our case, the substrate was the same yet this still led to variability in fungal colonization.

Regardless, a possible reason for differences between the 2 waters may be that fungi were not as productive in the wetland water as in the river water. The treatments in which tetracycline was used seem to indicate bacterial inhibition of fungi. In the river water treatment, fungal biomass in the $4000 \mu \mathrm{g} \mathrm{l}^{-1}$ treatment increased from the control by approximately 3 times, while the increase was 6 times in the wetland water for the same treatment. This suggests that fungi in the wetland water, unlike in the river water, were either being inhibited or limited by other microbes. Most previous studies indicated that associations between bacteria and fungi were antagonis1993, Moller et al. 1999, Mille-Lindblom \& Tranvik 2003, Mille-Lindblom et al. 2006a). Despite inhibition by bacteria, fungi have been found to dominate litter decomposition processes in both aquatic and terrestrial systems (de Boer et al. 2003). Unfortunately, because of the large variations in fungal biomass, the results from the present study are inconclusive.

Total microbial cell volume in the tetracycline treatments was considerably reduced in the river and wetland waters compared to the control treatments. This tic rather than synergistic (Flegler et al. 1974, Padgett 


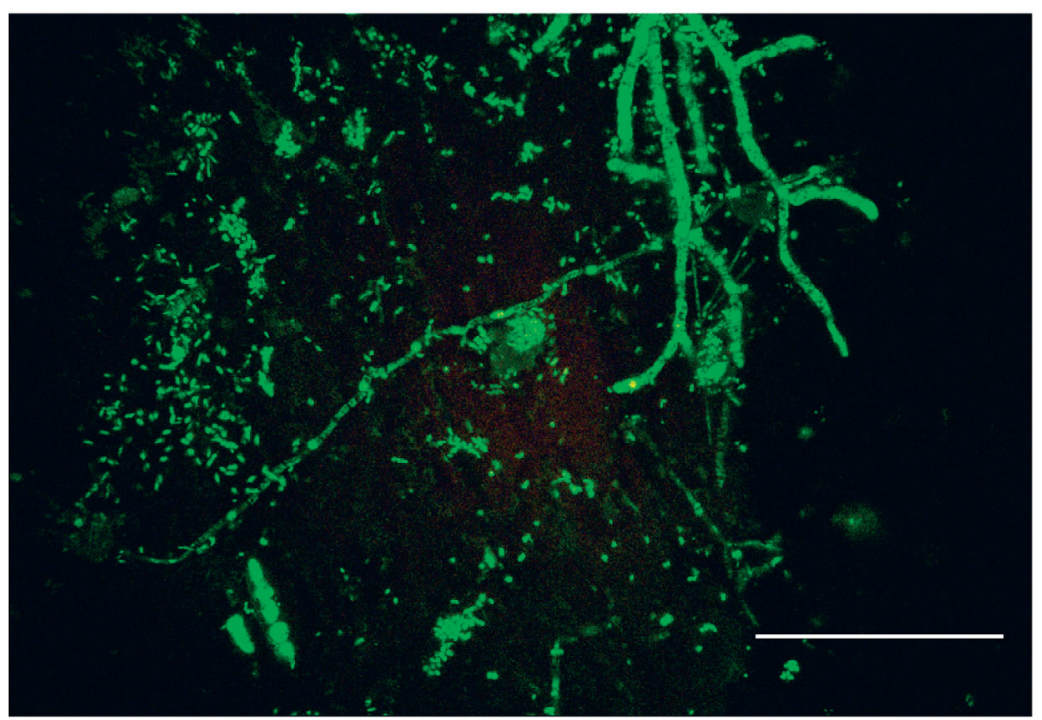

Fig. 3. Biofilm (14 d old), stained with SYTO-9, on the surface of Scirpus lacustris decaying in wetland water, with fungal and bacterial cells fluorescing equally. Note the presence of numerous bacterial cells on or near the fungal hyphae. Scale bar $=50 \mu \mathrm{m}$
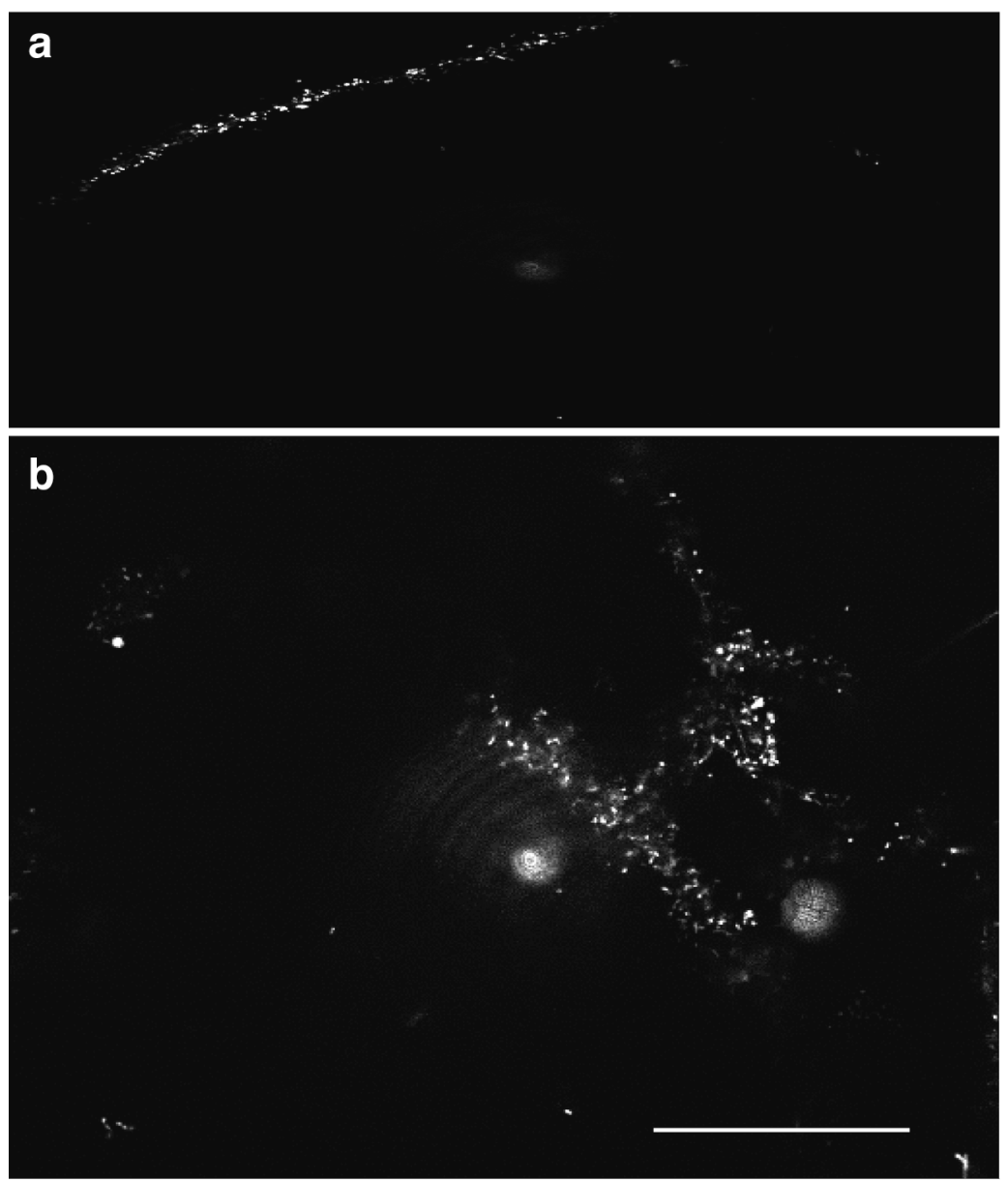

Fig. 4. Surface of dead fungal hypha colonized by bacteria from wetland water control at (a) Day 10 and (b) Day 33 of the $33 \mathrm{~d}$ immersion experiment. Scale bar (for both panels) $=50 \mu \mathrm{m}$ reduction in both experiments was expected because tetracycline is known to inhibit protein synthesis in susceptible bacteria (Brodersen et al. 2000, Chopra \& Roberts 2001, Nester 2004). Tetracycline binds to the 30 s subunit of the 70 s bacterial ribosome and prevents the association of the ribosome with aminoacyltRNA, thereby hindering the production of protein (Brodersen et al. 2000, Chopra \& Roberts 2001). This suggests that large inputs of tetracycline in wetlands near agriculturally intensive operations may have a marked effect on the colonization, and therefore the decomposition, of plant litter. However, if there is a concomitant increase in fungal biomass due to bacterial suppression, the overall process of decomposition may not be significantly compromised.

During the course of the experiments, it was observed that bacteria were present on or near living fungal hyphae (Fig. 3) but it was not determined if this was fortuitous or if it was an active process indicating a symbiotic relationship between the bacteria and fungi. Further, after Day 10 many of the fungal hyphae had turned brown and were increasingly colonized by bacteria (Fig. 4). The fungal hyphae appeared to be dead as they did not take up SYTO-9 stain. This is a novel observation for aquatic systems but not for soil systems: bacteria are known to colonize living and dead fungal hyphae in terrestrial decay systems (Brock 1966). It is likely that the bacteria near live hyphae were obtaining breakdown products of the litter while those on the dead hyphae were using the dead fungi as a carbon source. These possibilities require further research.

We also noted the presence of considerable quantities of algal cells in the biofilms of decomposing Scirpus lacustris litter (see Fig. 1). The role of algae in aquatic plant decomposition has, to the best of our knowledge, been overlooked and not been investigated.

As an aid to future researchers, we note the likely reason for the very large variations in microbial cell volumes and fungal hyphae measured on the surface of the Scirpus lacustris stems and suggest a way to overcome this. The S. la- 


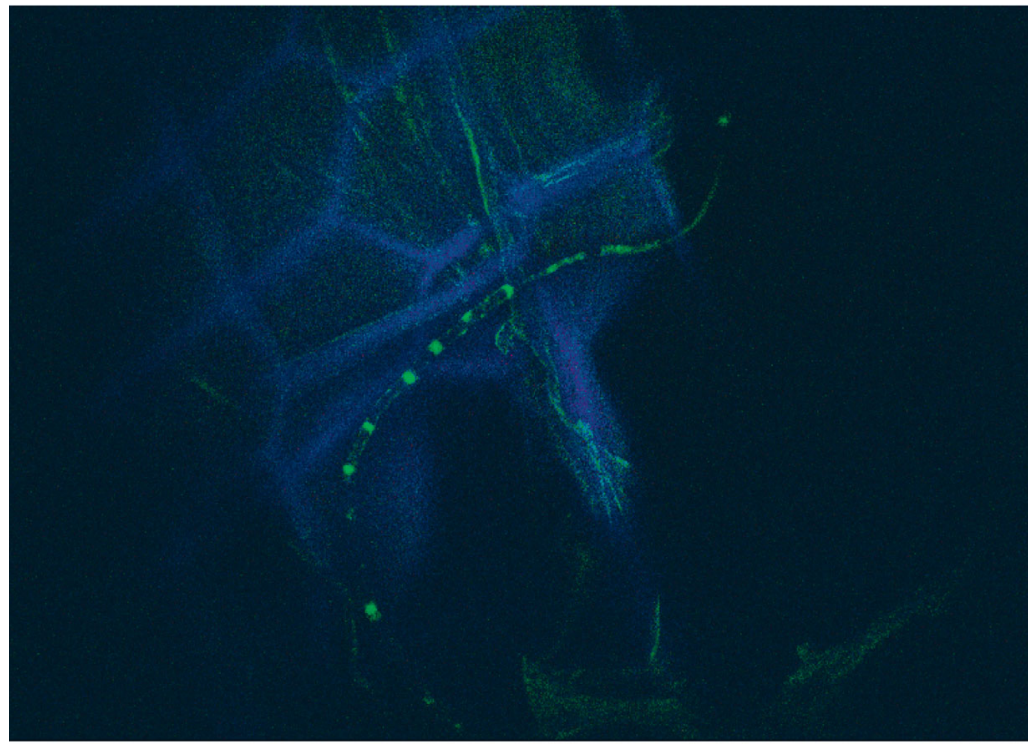

Fig. 5. CLSM scan showing a fungal hypha, fluorescing green with SYTO-9, penetrating the cell walls (blue) of a Scirpus lacustris stem, sectioned longitudinally and scanned $14 \mathrm{~d}$ after being allowed to decay in wetland water posed regions. These variations could be minimized in future studies if living stems were harvested and immersed to decay instead of using dead and intermittently decomposed stems because the surface structure would be more intact and uniform.

CLSM followed by image analysis is an appropriate and promising tool to nondestructively measure the dynamics of microbial colonization on the surface of decaying litter. However, one significant weakness of this technique is that it will underestimate microbial biovolume. This is due to the fact that litter breakdown occurs not only at the surface but concurrently inside opaque plant tissue (Fig. 5), which the laser is unable to penetrate. However, other methods, such as DAPI counts, also have the same limitation, as bacterial cells growing within plant material are difficult to extract and count. custris we used was from the previous year's stand and was standing dead on the periphery of Pond 50 when harvested. This means that from the time they died to when we harvested them they were exposed to the environment and, under favorable conditions, would have been colonized and decomposed by microbes (Verma et al. 2003). The decomposition would not have occurred homogeneously over the entire surface of the stem, but rather in patches, resulting in a patchwork pattern with some parts of the stem decomposed while other parts would have remained intact. Some factors that would have determined the unevenness of decomposition include a southern (drier plus greater solar radiation) vs. northern exposure, impinging rainfall and wind action, resulting in uneven moisture on the stem and surface features. This is corroborated by CLSM work done prior to submersion of the stems. During CLSM, it was observed that some areas did not have the outer or cuticular covering, while in other areas the surface layer was intact. Moreover, we also observed 'fungal tracks', black decomposed areas on the surface of the plant in the same shape, in one dimension, as fungal hyphae where fungi had lain. Presumably, enzymes were secreted by the fungi, broke down the substrate and then were re-absorbed so that the shape of the 'fungal track' was similar to the hyphae. Upon immersion of these stems, the portions that were not decomposed and still had labile carbon and nutrients were preferentially colonized, while the decomposed parts were avoided. Microbial colonization in previously decomposed stem regions would be sparse, while the opposite would be true in the non-decom-
Acknowledgements. We thank M. Hiltz of Alberta Research Council for help with statistical analysis and J. R. Lawrence for the use of the CLSM. K. Supeene, G. Swerhone and R. Schmidt are thanked for technical assistance. The Institute for Wetland and Water Research of Ducks Unlimited is thanked for financial support, and National Water Research Institute of Environment Canada for use of laboratory space and equipment. We also thank 3 reviewers for their comments and suggestions.

\section{LITERATURE CITED}

Baldy V, Gessner MO, Chauvet E (1995) Bacteria, fungi and the breakdown of leaf litter in a large river. Oikos 74: 93-102

Baldy V, Chauvet E, Charcosset JY, Gessner MO (2002) Microbial dynamics associated with leaves decomposing in the mainstem and floodplain pond of a large river. Aquat Microb Ecol 28:25-36

Brock TD (1966) Principles of microbial ecology, PrenticeHall, Englewood Cliffs, NJ

Brodersen DE, William M, Carter AP, Morgan-Warren RJ, Wimberly BT, Ramakrishnan V (2000) The structural basis for the action of the antibiotics tetracycline, pactamycin, and hygromycin $b$ on the 30 s ribosomal subunit. Cell 103: 1143-1154

Caldwell DE, Korber DR, Lawrence JR (1992) Confocal laser microscopy and digital image analysis in microbial ecology. Adv Microb Ecol 12:1-67

Chopra I, Roberts M (2001) Tetracycline antibiotics: mode of action, applications, molecular biology, and epidemiology of bacterial resistance. Microbiol Mol Biol Rev 65:232-260

de Boer W, Verheggen P, Gunnewiek P, Kowalchuk GA, van Veen JA (2003) Microbial community composition affects soil fungistasis. Appl Environ Microbiol 69:835-844

Flegler SL, McNabb CD, Fields WG (1974) Antibiotic treatment of lake sediments to determine effect of fungi on decomposition. Water Res 8:307-310 
Gessner MO, Newell SY (2002) Biomass, growth rate, and production of filamentous fungi in plant litter. In: Hurst CJ, Crawford RJ, Knudson G, McInerny M, Stetzenbach LD (eds) Manual of environmental microbiology. ASM Press, Washington, DC, p 390-408

Gessner MO, Thomas M, Jeanlouis AM, Chauvet E (1993) Stable successional patterns of aquatic hyphomycetes on leaves decaying in a summer cool stream. Mycol Res 97: 163-172

Gulis V (2001) Are there any substrate preferences in aquatic hyphomycetes? Mycol Res 105:1088-1093

Gulis V, Suberkropp K (2003) Effect of inorganic nutrients on relative contributions of fungi and bacteria to carbon flow from submerged decomposing leaf litter. Microb Ecol 45: 11-19

Hamscher G, Sczesny S, Hoper H, Nau H (2002) Determination of persistent tetracycline residues in soil fertilized with liquid manure by high-performance liquid chromatography with electrospray ionization tandem mass spectrometry. Anal Chem 74:1509-1518

Hieber M, Gessner MO (2002) Contribution of stream detrivores, fungi, and bacteria to leaf breakdown based on biomass estimates. Ecology 83:1026-1038

Lawrence JR, Korber DR, Wolfaardt GM, Caldwell DE (1997) Analytical imaging and microscopy techniques. In: Hurst CJ (ed) Manual of environmental microbiology. ASM Press, Washington, DC, p 29-51

Lawrence JR, Nie TR, Swerhone GDW (1998) Application of multiple parameter imaging for the quantification of algal, bacterial and exopolymer components of microbial biofilms. J Microbiol Methods 32:253-261

Mille-Lindblom C, Tranvik LJ (2003) Antagonism between bacteria and fungi on decomposing aquatic plant litter. Microb Ecol 45:173-182

Mille-Lindblom C, von Wachenfeldt E, Tranvik LJ (2004) Ergosterol as a measure of living fungal biomass: persistence in environmental samples after fungal death. J Microbiol Methods 59:253-262

Mille-Lindblom C, Fischer H, Tranvik LJ (2006a) Antagonism between bacteria and fungi: substrate competition and a possible tradeoff between fungal growth and tolerance towards bacteria. Oikos 113:233-242

Mille-Lindblom C, Fischer H, Tranvik LJ (2006b) Litter-associated bacteria and fungi-a comparison of biomass and communities across lakes and plant species. Freshw Biol 51:730-741

Moller J, Miller M, Kjoller A (1999) Fungal-bacterial interaction on beech leaves: influence on decomposition and dis-

Editorial responsibility: Jim Ammerman,

New Brunswick, New Jersey, USA solved organic carbon quality. Soil Biol Biochem 31: 367-374

Nester EW (2004) Microbiology: a human perspective, 4th edn. McGraw Hill, Boston, MA

Neu TR, Swerhone GDW, Böckelmann U, Lawrence JR (2005) Effect of CNP on composition and structure of lotic biofilms as detected with lectin-specific glycoconjugates. Aquat Microb Ecol 38:283-294

Newell SY (1996) The C-14 acetate-to-ergosterol method: factors for conversion from acetate incorporated to organic fungal mass synthesized. Soil Biol Biochem 28:681-683

Newell SY (2003) Fungal content and activities in standingdecaying leaf blades of plants of the Georgia coastal ecosystems research area. Aquat Microb Ecol 32:95-103

Padgett DE (1993) Distinguishing bacterial from nonbacterial decomposition of Spartina alterniflora by respirometry. In: Kemp PF, Kemp KF, Sherr BF, Cole JJ, Sherr EB (eds) Handbook of methods in aquatic microbial ecology. Lewis, Boca Raton, FL, p 465-469

Suberkropp K, Weyers H (1996) Application of fungal and bacterial production methodologies to decomposing leaves in streams. Appl Environ Microbiol 62:1610-1615

Thormann MN, Bayley SE, Currah RS (2001) Comparison of decomposition of belowground and aboveground plant litters in peatlands of boreal Alberta, Canada. Can J Bot 79: 9-22

Van Der Valk AG, Davis CB (1978) Primary production of prairie glacial marshes. In: Good RE, Whigham DF, Simpson RL (eds) Freshwater wetlands ecological processes and management potential. Academic Press, New York, p 21-37

Verma B, Robarts RD, Headley JV (2003) Seasonal changes in fungal production and biomass on standing dead Scirpus lacustris litter in a northern prairie wetland. Appl Environ Microbiol 69:1043-1050

Verma B, Robarts RD, Headley JV (2007) Impacts of tetracycline on planktonic bacterial production in prairie aquatic systems. Microb Ecol (published online Jan 31, ahead of print)

Waiser MJ (2001) Nutrient limitation of pelagic bacteria and phytoplankton in four prairie wetlands. Arch Hydrobiol 150:435-455

Wolfaardt GM, Lawrence JR, Korber DR (1999) Function of EPS in microbial biofilms. In: Wingender J, Neu TR, Flemming HC (eds) Microbial extracelluar substances. Springer Verlag, Berlin, p 171-200

Wrubleski DA, Murkin HR, vanderValk AG, Nelson JW (1997) Decomposition of emergent macrophyte roots and rhizomes in a northern prairie marsh. Aquat Bot 58:121-134

Submitted: August 18, 2005; Accepted: October 2, 2006

Proofs received from author(s): March 20, 2007 